\title{
Impact of Motivational Factors on Job Productivity of Library Staff of Rivers State University
}

\author{
VIVIEN O. EMMANUEL PhD \\ Department Of Library and Information Science, Rivers State University, Nkpolu-Oroworukwo, Port Harcourt, \\ Nigeria. \\ viviene@yahoo.com
}

\begin{abstract}
The study investigated impact of motivational factors on job productivity of library staff of Rivers State University (RSU). A research question and a null hypothesis were formulated to guide the study.. The design adopted for the study was correlational while the population of the study was 37 staff of Library department of Rivers State University (comprising 25 professional and 12 non-professional staff) which purposively was selected as the sample of the study. The study made use of a researcher made rating scale. The Research question was answered with Pearson Product Moment Correlation (PPMC). Regression analysis was used to test the hypothesis at 0.05 level of significance. The study finds out that there is positive relationship between motivational factors variables (financial incentives, training, appraisal and job productivity of library staff of Rivers State University (RSU). Also, the study found that library staff of RSU have a high level of job productivity. Promotion, salary increment are some of the ways to improve the job productivity of library staff of Rivers State. Hence, the study recommends that government should increase library staff salary to enhance optimum productivity.
\end{abstract}

DOI: $10.7176 / \mathrm{IKM} / 9-6-08$

Publication date:July $31^{\text {st }} 2019$

\subsection{Introduction}

Motivation comes from the Latin word "movere" which means to move (Igboeli 2000). It is an overall term that refers to all those inner forces such as cravings, drives or aims, wishes etc. which ignite, direct and sustain behaviour towards a goal.

The impact of motivation on the job productivity of librarians could be vast. A motivated librarian under normal circumstances would be a happy, joyous and at the same time a productive librarian. This is because, when the librarian is happy he/she will under normal circumstances be willing to relate well with the people in his/her working environment, such as colleagues and patrons and at the same time be willing to give his/her best to his clients. In other words, a motivated librarian does not need to be pressured to do his/her normal duties, but will rather be willing to discharge his/her professionally duties effectively. A motivated librarian would be willing to do everything possible to optimize his productivity since this has direct bearing on the total organizational productivity.

Academic library is the engine room of every tertiary institution, and any tertiary institution without a library is like a vehicle without an engine. Academic libraries serve as centres of communication ensuring useful means of gaining knowledge leading to understanding the minds of individuals and groups. Academic libraries set up their services to enhance the teaching and research missions of the institutions, particularly for users. For a library to achieve its set objectives, quality and seasoned personnel are required. It is imperative to note that the effectiveness of a library does not only depend on the resources and facilities therein but also on attitude of the personnel towards the users. The extent to which academic libraries perform these functions will depend on a number of factors, which include well motivated staff.

The essence of motivational scheme is to increase productivity, so when people are not sensitive to it, it will not be effective. The academic librarian as a motivational manager should adopt motivational design that will enforce the desired behaviour of the library employees, such as wages/salaries, promotion, conducive work environment, staff training and retraining, staff relationship etc. These measures will undoubtedly lead to increase in job productivity in the library. Ezeji (2007) in line with this, states that the application of motivational programmes in an establishment leads to increase in job productivity. Ayeni and Popoola (2007) on strategies of motivational staff, listed the following measures; salary, wages and condition of service, money, staff training, information availability and good communication. They believe that in using salary as a motivator, 
personnel managers should consider job rates; as it relates to the importance the organization attach to each job payment which encourages workers or groups by rewarding them according to their performances.

Based on the foregoing, it is understood that job productivity is dependent of motivational factors. Library managers are currently adopting different motivational theories (factors) for increased job productivity but the impact of these factors on job productivity may not be the same in all academic libraries. It is against this background that this study is set to determine the impact of motivational factors on job productivity of library staff of Rivers State University Library.

\subsection{Objective of the Study}

The general purpose of the study is to examine motivational factors and job productivity of library staff in Rivers State University, Port Harcourt. Specifically the study seeks to:

determine the contributions of motivational factors on job productivity of library staff of Rivers state University.

\subsection{Hypothesis}

In line with objective of the study, the following hypothesis was formulated to establish the significance of the solution:

Ho: There is no significant difference in the mean responses of professional and non-professional library staff on the contribution of the motivational factors on job productivity among library staff of rivers State University.

\subsection{Review of Related Literature}

Motivation as a concept has attracted different definitions from different scholars because it is applied in various ways to perform managerial functions. Ukwuoma and Akanwa (2008) defined motivation to mean, to inspire and to stimulate the interest of one that may want to do more. Emmanuel (2006) opined that motivation of staff is necessary for productivity and is very complex. It is inseparable from the realization of organizational as well as individual goals, values, psych needs and life experiences. Vruom (2010) referred to motivation as a process that governs individual choice among different forms of voluntary activities. According to Olusegun (2012), motivation is the stimulus, incentive or inducement to act or react in a certain way. Motivation is a drive that compels one to act because human behaviour is directed towards some goals.

\subsection{Training and Job Performance}

Training is a very important device in personnel management considering the fact that information provision to every user is the mission of the library. The need for training is an essential strategy for motivating workers in the library as a service organization. The library cannot do without adequate training of their workers to be dynamic enough to cope with the changing needs of the public who make up their user population. Ajidahun (2007) enumerated some common training techniques about which researchers on management, personnel development and career development consider very relevant for the development of library personnel. They are as follows: study visits, in-service training, on-the-job training, training programmes by international organizations, institutional training programmes and conferences, seminars and workshops. An organization may have employees with the ability and determination, with the appropriate equipment and managerial support yet productivity falls below expected standards. The missing factor in many cases is the lack of adequate skills and knowledge, which is acquired through training and development.

\subsection{Performance Appraisal}

Jobs performed by staff of organizations need to be appraised from time to time so as to see if they are carrying out their duties as expected. Mathis and Jackson (2000) saw performance appraisal as the process of evaluating how well employees perform in their jobs when compared to the set standard, and then communicating that information to those employees. Performance appraisal in academic libraries is therefore a means of control through which library administrators monitor the job performances of subordinates by observing variance between set goals, actual performance and taking corrective actions (Kleiner, 2006; Schachter, 2004).

\subsection{Job Productivity}


Productivity is conceptualized to mean the ability to produce an item or service in the organization. Also, it refers to all efforts that an individual employee exerts towards the general production of goods and services of the organization with the least input of skills, labour, material, and machines. In Nigerian university libraries, librarians' productivity entails providing current and relevant educational resources in the library that would encourage increase in paper publications among faculty members and librarians themselves, innovative research works in the university that would attract grants from both local and international organizations, among other accrued benefits. This helps in promoting the image and status of the university among her peers. Hence, it becomes logical that librarians should be adequately be motivated by their employers. They have to be emotionally stabled if they are to increase the rate of their productivity in the university system (Yaya, Akintayo \&Uzohue, 2016).

Ogunsanwo (2012) defined productivity as the rate at which a worker, an organization, or a country produces goods and services. Employee's productivity is generally acknowledged as a necessary factor that enhances the growth and development of every organization in the human society.

Paso (2003) stated that team and departments function better when their leaders have information about team member's strength. This assertion supports the fact that an academic librarian should endeavour to apply intracommunication system and this agrees with Desler in Onwubiko (2004) who believes that any motivational approach adopted by the library cannot achieve the desired result if an intra-communication system that encourages openness is not adopted.

\subsection{Research Methodology}

For the purpose of this study, the research design adopted is correlational design. The population of the study comprises of 37 library staff made up of 15 professionals and 22 non-professionals of Rivers State University. The entire population was used for the study which is known as census enumeration. Hence, the sample size is 37 library staff, made of 15 professionals and 22 non-professionals. Self-designed rating scale was used as instrument for data collection. The instrument was designed on a four-point rating scale which was used to collect data that provided answer to the research question and hypothesis raised in this study. To answer the research question so as to determine the linear relationship between dependent and independent variables of the study, PPMCC was used while the hypothesis was tested using t-test at 0.05 level of significance.

\subsection{Data Analysis and Presentation \\ Research Question:}

What are the contributions of the motivational factors on job productivity of library staff of Rivers State University?

Table 1: Mean response of professional library staff on the contributions of the motivational factors on job productivity of library staff of Rivers state University.

\begin{tabular}{|c|c|c|c|c|c|c|c|c|c|}
\hline \multirow[t]{2}{*}{$\mathbf{S} / \mathbf{N}$} & \multirow{2}{*}{$\begin{array}{l}\text { Contributions of the motivational factors } \\
\text { to the following variables of job } \\
\text { productivity of library staff of Rivers } \\
\text { state University }\end{array}$} & \multicolumn{4}{|c|}{$\begin{array}{l}\text { Professional } \\
\text { Library Staff } \\
\text { Response }\end{array}$} & \multirow[t]{2}{*}{$\begin{array}{c}\text { Mean } \\
\frac{x}{x}\end{array}$} & \multirow[t]{2}{*}{$\begin{array}{l}\text { Std. } \\
\text { Dev. }\end{array}$} & \multirow[t]{2}{*}{$\begin{array}{l}\text { Total } \\
\text { no. of } \\
\text { Staff }\end{array}$} & \multirow[t]{2}{*}{ Decision } \\
\hline & & 4 & 3 & 2 & 1 & & & & \\
\hline 1 & $\begin{array}{l}\text { Guiding library users on how to make } \\
\text { effective use of the library }\end{array}$ & 4 & 8 & 2 & 1 & 3.0 & 0.82 & 22 & Agree \\
\hline 2 & $\begin{array}{l}\text { Selecting current and relevant library } \\
\text { collections for students to access }\end{array}$ & 2 & 10 & 2 & 1 & 2.87 & 0.72 & 22 & Agree \\
\hline 3 & Always available in response to duty calls & 4 & 9 & 2 & - & 3.1 & 0.81 & 22 & Agree \\
\hline 4 & $\begin{array}{l}\text { Working overtime during accreditation } \\
\text { exercise }\end{array}$ & 5 & 7 & 2 & 1 & 3.07 & 0.85 & 22 & Agree \\
\hline 5 & $\begin{array}{l}\text { A member of the professional association of } \\
\text { librarians and with scholarly articles } \\
\text { published in both local and international } \\
\text { journal journals. }\end{array}$ & 5 & 7 & 3 & - & 3.1 & 0.72 & 22 & Agree \\
\hline
\end{tabular}

Table 1 shows that mean ratings of 3.0, 2.87, 3.1, 3.07 and 3.1 respectively, which are greater than the standard reference mean of 2.50 , indicates that professional library staff were of the view that motivational factors 
contribute to the following variables of job productivity among library staff attain the following levels of job productivity; guiding library users on how to make effective use of the library, selecting current and relevant library collections for students to access, always available in response to duty calls, working overtime during accreditation exercise and belonging as a member of the professional association of librarians and with scholarly articles published in both local and international journal journals. Small standard deviations obtained, i.e. 0.82, $0.72,0.81,0.83$ and 0.72 respectively, indicates that the professional library staff were homogenous in their response.

Table 2: Mean response of non-professional library staff on the contributions of the motivational factors on job productivity of library staff of Rivers state University

\begin{tabular}{|c|c|c|c|c|c|c|c|c|c|}
\hline \multirow[t]{2}{*}{$\mathbf{S} / \mathbf{N}$} & \multirow{2}{*}{$\begin{array}{l}\text { Contributions of the motivational factors } \\
\text { to the following variables of job } \\
\text { productivity of library staff of Rivers } \\
\text { state University }\end{array}$} & \multicolumn{4}{|c|}{$\begin{array}{l}\text { Professional } \\
\text { Library Staff } \\
\text { Response }\end{array}$} & \multirow[t]{2}{*}{$\begin{array}{l}\text { Mean } \\
-\bar{x}\end{array}$} & \multirow[t]{2}{*}{$\begin{array}{l}\text { Std. } \\
\text { Dev. }\end{array}$} & \multirow[t]{2}{*}{$\begin{array}{l}\text { Total } \\
\text { no. of } \\
\text { Staff }\end{array}$} & \multirow[t]{2}{*}{ Decision } \\
\hline & & 4 & 3 & 2 & $\mathbf{1}$ & & & & \\
\hline 1 & $\begin{array}{l}\text { Guiding library users on how to make } \\
\text { effective use of the library }\end{array}$ & 7 & 11 & 3 & 1 & 3.09 & 0.79 & 22 & Agree \\
\hline 2 & $\begin{array}{l}\text { Selecting current and relevant library } \\
\text { collections for students to access }\end{array}$ & 5 & 14 & 2 & 1 & 3.05 & 0.71 & 22 & Agree \\
\hline 3 & Always available in response to duty calls & 3 & 16 & 2 & 1 & 2.95 & 0.81 & 22 & Agree \\
\hline 4 & $\begin{array}{l}\text { Working overtime during accreditation } \\
\text { exercise }\end{array}$ & 4 & 15 & 2 & 1 & 3.0 & 0.67 & 22 & Agree \\
\hline 5 & $\begin{array}{l}\text { A member of the professional association of } \\
\text { librarians and with scholarly articles } \\
\text { published in both local and international } \\
\text { journal journals. }\end{array}$ & 6 & 13 & 2 & 1 & 3.09 & 0.73 & 22 & Agree \\
\hline
\end{tabular}

Table 2 shows that mean ratings of 3.09, 3.05, 2.95, 3.0 and 3.09 respectively, which are greater than the standard reference mean of 2.50 , indicates that non-professional library staff were of the view that motivational factors contribute to the following variables of job productivity among library staff attain the following levels of job productivity; guiding library users on how to make effective use of the library, selecting current and relevant library collections for students to access, always available in response to duty calls, working overtime during accreditation exercise and belonging as a member of the non-professional association of librarians and with scholarly articles published in both local and international journals. Small standard deviations obtained, i.e. $0.79,0.71,0.81,0.67$ and 0.73 respectively, indicates that the non-professional library staff were homogenous in their response.

\section{Hypothesis}

There is no significant difference in the mean responses of professional and non-professional library staff on the contributions of the motivational factors on job productivity among library staff of Rivers State University.

Table 3: Z-test of Differences in the Mean Responses of professional and Nonprofessional library staff on the contributions of the motivational factors on job productivity among library staff of Rivers State University.

\begin{tabular}{|c|c|c|c|c|c|c|c|c|}
\hline \multirow[b]{2}{*}{ Group } & \multirow{2}{*}{$\frac{\text { Mean }}{X}$} & \multirow{2}{*}{$\begin{array}{c}\text { Std. } \\
\text { dev } \\
\varnothing\end{array}$} & \multirow[b]{2}{*}{$\mathbf{N}$} & \multirow[b]{2}{*}{ Df } & \multirow{2}{*}{$\begin{array}{c}\text { Std. } \\
\text { error }\end{array}$} & \multirow[b]{2}{*}{$\mathrm{Z}_{\text {cal }}$} & \multirow{2}{*}{$\begin{array}{l}\mathbf{Z}_{\text {table }} \\
\alpha=0.05\end{array}$} & \multirow[t]{2}{*}{ Decision } \\
\hline & & & & & & & & \\
\hline $\begin{array}{l}\text { Professional library } \\
\text { staff }\end{array}$ & 3.03 & 0.78 & 15 & & & & & \\
\hline $\begin{array}{l}\text { Non }- \text { professional } \\
\text { library staff }\end{array}$ & 3.04 & 0.74 & 22 & 35 & 0.25 & 0.04 & 1.96 & $\mathrm{H}_{0}$ accepted \\
\hline
\end{tabular}

Table 3 above shows that z-test of the null hypothesis on differences in the mean responses of professional and non-professional library staff on the motivational factors utilized to enhance job productivity among library staff of Rivers State, was accepted at 5\% level of significance where the degrees of freedom (35) is at infinity $(\infty)$. This is because the calculated $Z\left(\mathbf{Z}_{\mathrm{cal}}=0.17\right)$ is less than the tabula value of $Z\left(\mathbf{Z}_{\text {table }}=1.96\right)$. This 
means that both professional and non-professional library staff hold the same views that motivational factors are utilized to enhance job productivity among library staff of Rivers State. These motivational factors include: good remuneration, harmonious working relationship, good working conditions and training.

\section{Findings}

In the research question and null hypothesis, which focused on the contributions of the motivational factors on job productivity of library staff of Rivers State University, the study found out that both professional and nonprofessional library staff hold the same views that the motivational factors utilized to enhance job productivity among library staff of Rivers State, include good remuneration, harmonious working relationship, good working conditions and training. This findings supports the views of Ukwuoma and Akanwa (2008) that defined motivation to mean, to inspire and to stimulate the interest of one that may want to do more. Emmanuel (2006) opined that motivation of staff is necessary for productivity and is very complex. It is inseparable from the realization of organizational as well as individual goals, values, psych needs and life experiences.

\subsection{Conclusion}

There is positive relationship between motivational factors (good remuneration, harmonious working relationship, good working conditions and training) and job productivity of library staff of Rivers State. It is therefore important for managerial/supervisory staff of library units in universities, to ensure that they utilize these motivational strategies for sustainable job productivity.

There is a significant relationship between motivational strategies and job productivity of library staff of the Rivers State University.

\section{Recommendation}

Based on the findings, the study recommends among other things that:

1. Government should increase library staff salary to enhance optimum productivity.

\section{References}

Ajidahun, C.O. (2007) The training, development and education of library manpower in information technology in university libraries in Nigeria. World Libraries, 17 (1), 18-28. Available at: www.worlib.org/vol17no1/Ajidahunprint-v17n18html. Accessed July 92018

Ezeji, C. (2007). Human resource management. Lagos: Saban Publishers

Igboeli, G. N. (2000). Management: A functional approach. Onitsha: Adson Educational Publishers.

Kleiner, F. (2006). Organizations. New York: Wiley.

Mathis, A. D. \& Jackson, J. H., (2002) Personnel contemporary perspectives and applications (3rd edition). St. Paul: West Publishing Company.

Ogunsanwo, G.A. (2012). You and your job: Attitude required for improving performance and productivity. Paper presented at the training workshop for junior staff of Library Unit of Yaba College of Technology. Held at Centre for Management Development (CMD), Magodo, Lagos, December.

Olusegun, O. S. (2012). Influence of motivation on turnover of library personal in some public universities in south-west, Nigeria. Library Philosophy and Practice. Available at: http://unllib.unl.edu/LPP/

Paso, P.M. (2003). The Psychology of action: Linking cognition and motivation to behaviour. New York: Guilford press.

Ukwuoma, S. C. \& Akanwa, P. C. (2008) Human resources development programmes in Nigerian academic libraries: A comparative study of universities in Imo State. Samaru Journal of Information Studies, 8 (2), 38-47.

Vruom, V. (2010) Work and motivation. New York: Wiley Rose.

Yaya, J. A., Uzohue, O. A. \& Akintayo, C. E. (2016) Emotional intelligence and productivity of librarians in public universities in Nigeria: A correlational approach. European Journal of Open Education and Elearning Studies, 1(1), 75-127. 